\title{
Without Merit: One Library's Attempt to Put "Merit" Back in "Merit Pay"
}

\section{Frada L. Mozenter and Lois Stickell}

This article outlines a proposal developed at the University of North Carolina of a method for awarding merit pay to librarians. The library has a two-tiered structure that includes faculty who are tenured and others who work on contract. Because of this, the Acting University Librarian created two task forces to investigate ways to make merit pay equitable. Each task force developed a proposal that eventually was merged into one document. This article examines the process of developing a plan for merit pay and library faculty reactions to the plan.

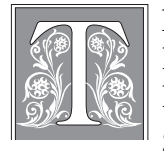

he University of North Carolina at Charlotte (UNC Charlotte) is a comprehensive, regional institution that gained university status within the University of North Carolina system in 1965. The university, which gained Doctoral Research Intensive status in 2000, is working toward ARL status. It is the fourth largest of the 17 UNC campuses. Enrollment for 2007 stands approximately at 21,500 students, including 4,400 graduate students. By 2020, enrollment is projected to be around $35,000 .{ }^{1}$ The university library, J. Murrey Atkins Library, is a centralized library facility with a small branch collection in the College of Architecture. It is the largest research library in the Southern Piedmont region. The library houses more than one million volumes, approximately 28,000 journal titles $(23,000$ of which are electronic), and over 900,000 government documents,. The library staff consists of 27 librarians and 62 support staff. Organizational units include Library Administration, Technical Services, Ac- cess Services, Special Collections, and the Information Commons. The Information Commons is composed of four service desks (Reference, Presentation Support, the Information Desk, and Circulation). Although Circulation is in this area, it is part of Access Services and not organizationally part of the Commons. Access Services incorporates Circulation and the Combined Services Desk.

Librarians at UNC Charlotte have had faculty status and eligibility for tenure since 1965.

In February 2003, the University Librarian called a special meeting of the then-29-member library faculty to inform them that the Interim Provost was instituting a new status for library faculty under special faculty appointments, as provided for in the University's tenure policy. ${ }^{2}$ This new career track would consist of non-tenure-track, multiyear appointments. The stated reason for this change was that University Administration believed that librarians would not be able to meet the more exacting standards

Frada L. Mozenter is Social Sciences Reference Librarian and Lois Stickell is History and Government Documents Reference Librarian in the Atkins Library at University of North Carolina at Charlotte; e-mail: flmozent@uncc.edu, lstickel@uncc.edu. 
regarding reappointment, tenure, and promotion toward which the university was moving. Librarians currently on tenure track or holding tenure had the options of staying on tenure track, retaining tenure and going through the post-tenure review process, or resigning from their tenure-track or tenured positions and signing multiyear contracts as Covered Library Faculty. Implementation of the new career path has meant having two career tracks - tenure-track and Covered Library Faculty (non-tenure-track). All new hires since the implementation of the new career path have been as non-tenure-track, Covered Library Faculty. As of January 2008, there are 11 tenured faculty (not counting the Acting University Librarian) and 16 covered librarians.

\section{Literature Review}

A search of the library literature for merit pay compensation revealed few articles that specifically look at merit pay for librarians. In general, articles about merit pay originate in the business and management literature. One significant library-specific study is Anderson and Cochenour's 2001 article “Merit Salary Criteria: One Academic Library's Experience." The authors detailed the work of a task force charged with developing criteria for merit salary increases at Colorado State University. The task force "decided that the criteria should be descriptive, focus on outcomes, and emphasize that each faculty is responsible for documenting his/ her contributions in terms of outcomes on the annual summary activity report."3

David A. Baldwin's 2003 book Library Compensation Handbook defines merit pay as "pay for performance." "Merit pay is defined as individual pay increases based on the rated performance of individual employees during a specific time period. ${ }^{5}$ Baldwin includes a brief history of merit pay, noting that the term is relatively new but the philosophy of "linking pay to performance dates back to the Protestant Reformation of the sixteenth and seventeenth centuries. Hard work was viewed as self-sacrifice in the service of God-hard work equaled economic success equaled willingness to serve God. Modern merit-pay plans began to appear around the early twentieth century. Many urban U.S. school districts had merit plans in the 1920s, and their use increased dramatically after World War II. Today, at least 80 percent of U.S. organizations have some type of merit-pay plan." 6

Richard I. Henderson, in Compensation Management in a Knowledge-Based World, while not directly addressing librarians or librarianship does define "knowledge-based pay" as "pay for knowledge." He notes that a "number of the original pay-for-knowledge plans were within banks and insurance companies and similar kinds of organizations in which large numbers of employees processed records-producing data and information instead of goods." ${ }^{7}$ While not all librarians process data, all deal with some form of information.

Carol F. Goodson in The Complete Guide to Performance Standards for Library Person$n e l^{8}$ addresses rating scales and methods of measuring performance in great detail but does not tie these to merit raises. Patricia Belcastro's Evaluating Library Staff: A Performance Appraisal System also examines the evaluation process without tying it to performance-based salary increases. ${ }^{9}$ Seaman, Krismann, and Hamilton in "An Internal Equity Evaluation System Based on Merit Measures" focus on salary equity but acknowledge the need to include merit in equity pay. The authors acknowledge the difficulty of quantifying merit, stating, "Because librarians have such diverse job duties and widely varying experience, assessing merit equity over an individual's entire academic career proved particularly challenging. What constitutes merit, how is it to be measured, and how much and where can supporting information be obtained? The system had to be fair and accurate, but also clear and understandable. A system that was too complex could be burdensome to those reassessing equity every year."10 
When looking at the issue of meritbased pay, it immediately becomes clear that librarians are in a unique position because much of what they do is difficult to quantify. As Henderson notes, "Because so much of the work goes on inside the brains of these knowledge-directed workers, it is very difficult to identify or recognize the quality of their contributions or outputs through observation or to quantify them."11 Nevertheless, library administrators need and want accurate ways of measuring and rewarding performance. Because there is no generally accepted standard, institutions are left to devise their own formulas or to rely on unwritten processes. Indiana University created a peer review process. ${ }^{12}$ Temple University worked from guidelines issued to carry out a collective bargaining contract with the Temple Association of University Professionals and based their merit awards "principally for outstanding performance in teaching/instruction and in research/scholarship/creative activity." ${ }^{13}$ Indiana University and Temple are exceptions rather than the rule, as most libraries leave salary decisions to administrators who often operate without written guidelines.

As discussed earlier, the guidelines for merit pay that do exist are often based on business models. The HR Series, in Policies and Practices, devotes a section to "Increases under Merit Pay Systems" and discusses how to design a merit system. While noting that "most employees want some control over their pay growth rate and most employers want to be able to reward the employees who contribute the most to their jobs, a merit system seems to be a good idea. However, a company must address several critical issues before deciding on or designing a merit pay system." These include the following: 1) whether the nature of the jobs allows for significant differences in job performance; 2) whether the performance differences are observable and measurable; 3) whether the salary ranges are large enough to allow "significant variations in pay for employees in the same job"; and 4) whether the company is willing to "expend resources on training managers to be good raters."14

In addition, types of work within libraries vary dramatically. As Anderson and Cochenour point out, "How does one rank the accomplishments of an instructional librarian against those of a serials librarian..."15 Their solution was that "merit should be determined by applying the criteria to one's job description and one's accomplishments as related to the predefined annual goals." 16

\section{Organizational Climate}

Merit pay resides within the overall framework of an organization's environment. Organizational structure, policies, processes, and procedures obscure the human factor: what Longnecker, Sims, and Gioia call a "mask of objectivity and rationality." 17 Nurse states that organizations are "arenas in which negotiations, networking, the formation of alliances and power blocks as well as the development of political strategies are commonplace events that play an important role in determining who gets what."18 He goes on to say that, given this environment, it is simply a myth that hard work leads to success. Rather, success is based on who one knows and how successful one is in mastering the "political arena" and the "political tools."19

Whether or not the theory of organization as political entity is always accurate, the question becomes, "do employees view it as such?" Lawler contends that performance appraisal systems that tie performance to pay often fail based not on the merit of the process but rather on the lack of trust between employee and supervisor. ${ }^{20}$ This refers back to the concept that a certain level of work will result in a specific amount of performance pay. Thus, the trust issue can be viewed by the employee as one of organizational justice. The literature states there are three types of organizational justice. The first, procedural justice, focuses on fairness 
of methods, policies, and procedures. The second, interactional justice, has at its core the treatment received by each employee. The third, distributive justice, is concerned with "the perceived fairness of the outcomes or allocations that individuals in organizations receive." ${ }^{21}$ Sylie St-Onge uses the terms "perceived instrumentality link" and "instrumentality perception" to describe the connection between perception and pay-for-performance or merit pay. ${ }^{22}$

The above hint at what managers must overcome if a merit pay system is to succeed. It also reflects what managers must do if they want the organization to succeed in its mission. As determined by a joint University of Maryland Libraries/University of Maryland Department of Industrial and Organization Psychology study, a "healthy organization is better able to fulfill its service mission." The actions of an organization that is perceived as violating the trust of its employees also have an impact on its customers. ${ }^{23}$

Making the issue of organizational climate even more challenging is that academic libraries are dissimilar not only from nonacademic instructions but also from other types of libraries. In many ways, they are also distinct from the wider university in which they operate. They also have internal unique cultural subsystems (public service, technical service, administration) further confounding a simple solution. ${ }^{24}$

At UNC Charlotte, the task of creating a framework for merit pay was complicated by the fact that there are two career tracks in the library. Because new hires are placed on the non-tenure track, librarians with seniority are the only ones with tenure. The decision to eliminate tenure-track positions had the unintended consequence of making non-tenure-track librarians ineligible for certain campus committees, grants, and even phased retirement. This has created some tension that has affected the organizational climate.

\section{Current System}

The library's current review process covers a calendar year, January 1 through December 31. Each librarian prepares a self-evaluation that delineates achievements as well as met or missed goals. The individual's supervisor writes an assessment based on this evaluation as well as his or her observations. The librarian may (depending on the supervisor) see a draft copy and make comments. The supervisor then prepares a final evaluation, which is signed by both. The signature does not acknowledge agreement with what has been written; only that it has been seen. The librarian may submit a rebuttal. All documents are filed in Library Administration. The Acting University Librarian has the option of writing an assessment.

\section{The Charge}

In May 2007, the Acting University Librarian asked two librarians to chair task forces charged with investigating criteria to be followed during annual evaluations, a point at which merit pay is distributed. She stated that her request was prompted by complaints about the unfairness of the current system and that people believed the system was based on personal favoritism rather than on job performance. Two task forces were created reflecting the library's two tracks, tenured and contract (also called "covered"). The only stipulations given were that "criteria" should be the focal point, that UNC Charlotte peer institutions should be surveyed, and that university personnel policies followed. The Acting University Librarian also wanted the proposed documents submitted to the complete library faculty for approval. The chair of the Tenured Task Force requested that the task forces be combined because annual merit evaluations and the distribution of annual merit pay is the same for both tenured and covered librarians. In addition, a librarian's primary work responsibilities are the same regardless of their tenure or covered status, and one funding allocation covers both groups. The Acting University Librarian denied the request. 
The chairs selected two additional librarians from their respective tracks, creating two task forces of three people each. The Tenured Task Force consisted of librarians from Reference, Special Collections, and Technical Services. The Covered Task Force was made up of librarians from Reference, Distance Education, and Staff Development/Instruction. Each group worked separately, creating distinctive processes and policies.

\section{The Tenured Task Force}

The Tenured Task Force began by establishing goals and a strategy. The task force acknowledged that the success of the instrument and process developed would depend on the development of credible, comprehensive measures of performance criteria. ${ }^{25}$ Frederic W. Cook noted that two requirements are needed for a successful plan. The first is a "credible system of measuring and evaluating performance" and the second is that "employees must perceive that differences in performance will be recognized and rewarded." ${ }^{26}$ R.H. Kroll noted that an effective evaluation is possible only if the employee knows "what he is supposed to do, how his performance will be measured, and against what standards." 27 In addition, it was important that the instrument be relatively easy to administer, be quantifiable, and allow for standardization across jobs. ${ }^{28}$ With these criteria in mind, the Tenured Task Force created the following goals:

- Develop criteria that establish work priorities that librarians and supervisors must address during the annual review

- Create an easy-to-use and easyto-understand assessment instrument resulting in a transparent process

- Demonstrate how supervisors and the Acting University Librarian will recommend merit pay increases based on established and mutually-agreed-upon criteria that reflect the library and university mission as well as department goals

- Develop an instrument and procedures that ensure individual librarians are rated fairly within the department and across departments

- Develop an instrument that can be used by the Acting University Librarian to determine annual merit raises in conjunction with an individual's self-assessment and the immediate supervisor's rating and written assessment

The strategy encompassed the following tasks:

- Review the literature

- Query libraries among UNC Charlotte's peer institutions and select UNC System libraries ${ }^{29}$

- Develop criteria based on the "Criteria for Review" noted in the Tenure Policies and Regulations of the Library Faculty of the University of North Carolina at Charlotte $^{30}$

- Follow procedures for annual reviews noted in the university's Academic Personnel Procedures Handbook ${ }^{31}$

- Develop sample criteria for some positions to use as examples

- Develop a clear, understandable system of establishing assessment forms, assessment criteria, priorities, methods of evaluation, and measurement

- Develop a timeline for selected review criteria

- Develop responsibilities of individuals, immediate supervisors, and the Acting University Librarian regarding selected review criteria

- Present various scenarios regarding lines of authority that impact the review process

- Document concerns with the criteria, process, and/or timeline

\section{Peer Institutions}

UNC Charlotte peer institutions and three UNC System libraries were contacted via e-mail. They were asked to provide information on the status of librarians at their institution: that is, whether or not they hold university faculty status; whether librarians are eligible for tenure or work on contracts; whether specific criteria are used to determine annual merit pay and, if so, what are the criteria; if specific 
criteria are used, are they weighted; are librarians in a unit or department ranked by a supervisor; and, finally, how are librarians in different units or departments compared against each other when it comes to distributing merit pay.

Eight of the sixteen peer institutions and one of the three University of North Carolina System schools contacted responded. Five peer institution libraries responded that no specific criteria are used for awarding merit pay. Three of these libraries have unionized representation with salary increases negotiated by union contracts. All but one of the rest of the respondents indicated that merit pay is based on performance. Several responding libraries mentioned goalsbased evaluation and assessment based on level of effectiveness in categories such as professional competency, professional service, library responsibilities, scholarship, and university service. Only George Mason University uses specific criteria, including the establishment of general performance ratings by supervisors for each librarian and rating specific criteria. However, because their criteria were very broad, including categories such as leadership, planning, communication, conflict management, and teamwork, the committee determined they would not be an appropriate model for UNC Charlotte. ${ }^{32}$

\section{The Instrument}

Since a review of the literature and the responses from UNC Charlotte's peer institutions revealed little that specifically addressed merit criteria of professional librarians in academic libraries or, more specifically, explicit criteria or formalized assessment instruments, the Tenured Task Force began to develop an instrument.

The plan was to individualize the instrument depending on the library unit, overall unit goals, and an individual's work responsibilities. It was also designed to progress in stages. In October, library units were to develop unit goals and objectives. In mid-November, each librarian, along with his or her immediate supervisor, was to:

- Review and revise the librarian's job description

- Review and revise individual goals

- Establish individual-specific criteria under each broad-based category for the following annual review cycle

- Complete an "Individual Annual Review Assessment Summary Form"

In June each librarian and his or her immediate supervisor would meet to review and revise the job description, individual goals, individual-specific criteria, and the "Individual Annual Review Assessment Summary Form." A mid-year review would provide flexibility in case of changes in an individual's job duties. At the end of the review cycle, the supervisor would complete an "Annual Review Assessment Summary, Supervisor's Form." This proposed process did not alter the current policy. Rather, it was designed to augment it. The individual's self-evaluation would not be affected. The supervisor would still provide a written assessment. In the event of a disagreement, the librarian could still submit rebuttal materials.

\section{Categories}

Three broad categories, based on the library's tenure document or the covered librarians' document, formed the basis of the instrument. For tenured librarians, these categories were: 1) Primary Job Responsibilities, which included Professional Competence and Teaching; 2) Scholarship and Research; and 3) Service. For the covered librarians these categories were: (1) Assigned Area of Responsibility; (2) Professional Activity and Scholarship; and (3) Service. The percentages assigned to each area would be tailored to an individual's status. Each broad category was to be assigned a "percentage" by the supervisor of each library unit, indicating the level of importance attributed to each function. For example, if the librarian being reviewed was tenured and required to publish, the Head of Reference might assign the category of Primary Job Re- 
sponsibilities, 80 percent; Scholarship and Research, 10 percent; and Service, 10 percent. If the librarian was "covered" and not required to publish, the Head of Reference would place no emphasis or less emphasis on "Scholarship and Research."

The head of a unit could ascribe some categories as relevant to all in the unit. For example, the Head of Reference might determine that categories such as General Competencies, Overall Work, Liaison Service to Faculty, or Reference Service applied to everyone in the Reference Department. However, an individual librarian and his or her supervisor could also select librarian-specific categories. For example, the Engineering Reference Librarian could have a category relating to "Patents," while the Architecture Reference Librarian could have a category relating to management of the Architectural Resource Center. In turn, each of these areas was to be broken down into specific criteria. For example, criteria under "Reference Service" could include "quality of general reference assistance to students and faculty," "quality of specialized reference assistance to students and faculty in assigned liaison areas(s)," "quality of assistance provided through the virtual reference service," "number of reference desk hours," and so on.

\section{Weights, Ratings, and Definitions}

After determining criteria, the next step was to provide a way to quantify a librarian's performance. The task force determined that it needed to provide a rating scale with labels, definitions, numerical ratings, and weights.

The task force chose five categories that would reflect various performance levels. Each category was given a label, a descriptive statement, and a numerical rating that would be assigned by the immediate supervisor to each subcategory to reflect the quantity and quality of an individual's work. Weights were set to span 10 (high) to 1 (low). The weight would note the degree of emphasis placed on subcategories by each librarian and his or her immediate supervisor. ${ }^{33}$ Thus, on the continuum, a " 10 " indicated a subcategory that constituted a major part of one's job responsibilities; the mid-range, a moderate part of one's job responsibilities; and a " 1 ," a minor part of one's job responsibilities. (See figure 1.)

Categories, percentages, and weights would be recorded on an "Individual Annual Review Assessment Summary Form." The form would be signed by the librarian and supervisor noting agreement on the plan.

\section{End-of-Year Review}

At the end of the year the immediate supervisor would complete the process by:

- assigning ratings for each individual criteria

- multiplying the weight by the rating

\begin{tabular}{|c|c|c|}
\hline \multicolumn{3}{|c|}{$\begin{array}{c}\text { FIGURE } 1 \\
\text { Weights, Ratings, and Definitions }\end{array}$} \\
\hline \multicolumn{3}{|l|}{ Weights } \\
\hline & 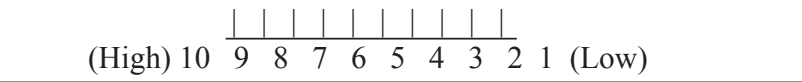 & \\
\hline $\begin{array}{l}\text { Rating Scale } \\
\text { Categories }\end{array}$ & Definitions & Ratings \\
\hline Exceptional & Performance generally superior. Frequently exceeds expectations. & $9-10$ \\
\hline Commendable & Performance above average. Generally exceeds expectations & $7-8$ \\
\hline Proficient & Performance meets standards. Makes a positive contribution & $5-6$ \\
\hline Marginal & Performance meets minimum standards & $3-4$ \\
\hline Unsatisfactory & Performance does not meet minimum standards & $1-2$ \\
\hline
\end{tabular}


- adding subsection weights and totals

- adding the total weights and the total totals for each broad category

- dividing the total total by the total weight for each broad category

- using these final totals to come up with an overall ranking

- recoding all data on an "Annual Review Assessment Summary, Supervisor's Form"

The form would be signed by the librarian and the supervisor. The librarian's signature meant only that s/he had read it, not that $\mathrm{s} /$ he agreed with the figures.

\section{Documents}

The Tenured Task Force submitted the proposal to the Acting University Librarian at the beginning of July 2007. Documents were broken into five groups. The first was an introductory document stating:
- goals

- strategy

- findings from the literature review

- findings from peer institutions and selected UNC System libraries

- definitions of categories, weights, rating scale categories, and other terms

- a suggested timeline

- responsibilities of immediate supervisors and the Acting University librarian

- concerns regarding lines of authority and training

- a proposal for a survey to be distributed one year after implementation

The second document was an example of the "Individual Annual Review Assessment Summary Form" with examples prior to the Annual Review Cycle. The third document was an example of the "Individual Annual Review Assessment

\begin{tabular}{|c|c|c|c|c|}
\hline \multicolumn{5}{|c|}{$\begin{array}{c}\text { FIGURE } 2 \\
\text { Institutions Posting Merit Pay Criteria Online }\end{array}$} \\
\hline & $\begin{array}{l}\text { Procedure for Awarding } \\
\text { Merit }\end{array}$ & $\begin{array}{c}\text { Teaching/ } \\
\text { Performance }\end{array}$ & $\begin{array}{c}\text { Research/ } \\
\text { Creative } \\
\text { Activity/Prof. } \\
\text { Development }\end{array}$ & Service \\
\hline $\begin{array}{l}\text { Indiana } \\
\text { University }\end{array}$ & $\begin{array}{l}\text { Faculty member receives a } \\
\text { rating and evaluation from } \\
\text { Peer Review Committee }\end{array}$ & Yes & Yes & Yes \\
\hline $\begin{array}{l}\text { University of } \\
\text { Central Florida }\end{array}$ & $\begin{array}{l}\text { Based on supervisor's } \\
\text { evaluation of } \\
\text { "Outstanding" or "Above } \\
\text { Satisfactory", etc. }\end{array}$ & Not indicated & Not indicated & $\begin{array}{c}\text { Not } \\
\text { indicated }\end{array}$ \\
\hline $\begin{array}{l}\text { University Of } \\
\text { South Florida }\end{array}$ & $\begin{array}{l}\text { Merit pay committee, } \\
\text { based on librarian's self- } \\
\text { ranking and self-evaluation } \\
\text { + supervisor's ranking }\end{array}$ & & & \\
\hline UNLV & $\begin{array}{l}\text { Faculty member must } \\
\text { apply. Merit advisory com- } \\
\text { mittee recommends using a } \\
\text { score sheet }\end{array}$ & Yes & Yes & Yes \\
\hline $\begin{array}{l}\text { Colorado State } \\
\text { University }\end{array}$ & $\begin{array}{l}\text { Recommended by } \\
\text { supervisor. Rankings } \\
\text { are: Superior, Quality; } \\
\text { Satisfactory; Unsatisfactory }\end{array}$ & $\begin{array}{l}\text { Performance } \\
\text { (which may } \\
\text { or may not } \\
\text { include } \\
\text { teaching) }\end{array}$ & Yes & Yes \\
\hline
\end{tabular}


Summary Form" with examples at the end of the Annual Review Cycle. The fourth document was the "Annual Review Assessment Summary Supervisor's Form," and the fifth document was a step-by-step set of instructions.

The task force also included a second request asking permission to contact and work with the Covered Task Force as the Tenured Task Force believed that it would be more beneficial for both groups to combine efforts. This time the Acting University Librarian granted the request.

\section{The Covered Task Force}

The Covered Task Force charged with investigating Merit Pay Criteria began by reviewing five institutions that had posted their merit pay criteria online. The five were Indiana University, University of Central Florida, University of South Carolina, University of Nevada at Las Vegas, and Colorado State University. For the purposes of their research, the Covered Task Force did not distinguish between librarians with tenure and librarians who are not tenured. The following table gives a brief summary of the procedure for awarding merit pay and whether teaching/performance, research/creative activity/professional development, and service were specifically addressed in merit pay decisions. The results for the five institutions appear in figure 2.

In the majority of cases, teaching/performance, research/creative activity/professional development, and service were addressed in the merit pay process, and the task force agreed these were the significant building blocks in creating a template for merit pay criteria. The task force created a chart that assigned a percentage to each of the three categories: primary professional duties; research, scholarship, creative activity; and service to the profession, university, and the public. It was the intent of the task force that this be a fluid document and that the percentages assigned to each of the three categories could change each year. For instance, if a librarian was heavily involved in research in a particular year, this might represent a higher percentage of his or her job that year but the following year that percentage could be adjusted downward as the amount of research decreased.

The second issue was who would be involved in making a determination about the quality of a librarian's work and what the ranking would be. The Covered Task Force determined that the librarian should write a self-review that a merit pay/peer review committee could then review, although this was determined to be an optional step. The final reviewer was the supervisor. Each of the reviewers would rate the librarian's work as Unacceptable, Weak, Satisfactory, Strong, Outstanding, or Not Applicable. The committee had some discussion over how to tie numbers to these ratings but decided this was not imperative. Based on these ratings, each of the reviewers would then recommend a salary increase of None, Minimum, Moderate, or Large.

The task force adapted the University of South Florida's "Annual Librarian Review Summary" and made some minor modifications. (See figure 3.)

\section{Compromise Documents}

The Tenured and Covered Task Forces held a joint meeting in mid-September 2007. The two committees reviewed the documents from both groups. The Tenured Task Force voiced concerns about the recommended percentages noted in the covered document because it was not clear on what they would be based. The Covered Task Force was concerned with the level of detail and the amount of math that would have to be done in the documents presented by the Tenured Task Force. Since the Tenured Task Force also had concerns about the complexity and since both groups relied on versions of the University of South Florida's "Annual Librarian Review Summary," the major decision was to use the tenured group's recommendations but collapse the categories. Both groups agreed this would make less work for all involved. 


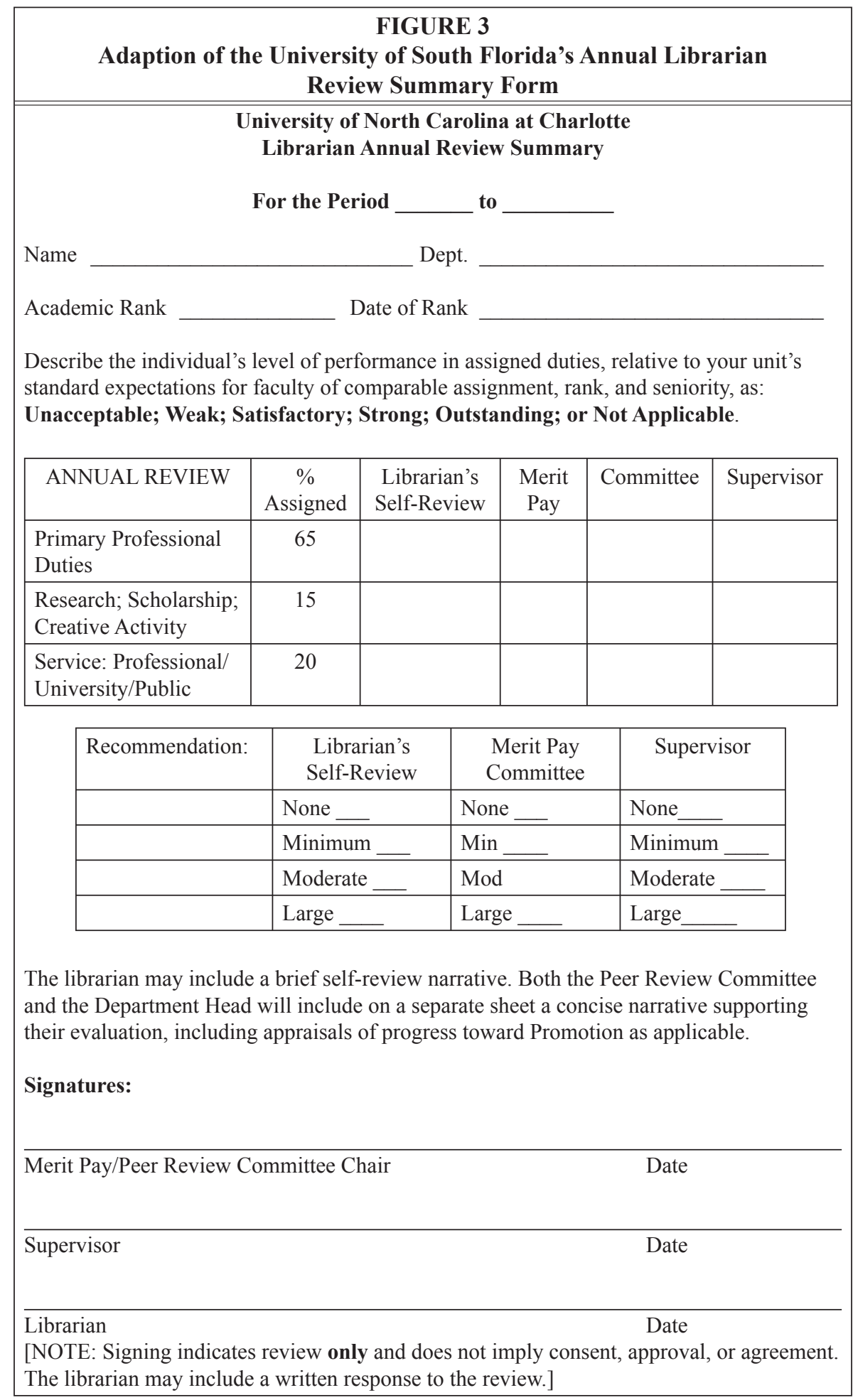


Three broad categories, based on the library's tenure document or the covered librarian's document (depending on the librarian's status), formed the basis of the instrument. For the tenured librarians, these categories were: 1) Primary Job Responsibilities, which included Professional Competence and Teaching; 2) Scholarship and Research; and 3) Service. For the covered librarians these were: (1) Assigned Area of Responsibility; (2) Professional Activity and Scholarship; and (3) Service. The percentages assigned to each area would be tailored to an individual's status.

Supervisors of each unit would determine subcategories under each section. Some might be common to all individuals in the unit, while others would be unique to an individual. The rating and weighting system remained as in the Tenured Task Forces process. The step-by-step instructions were enhanced with diagrams and examples for each step.

The joint documents were forwarded to the Acting University Librarian on October 29, 2007. On November 27, the entire library faculty had a chance to respond with comments and concerns. (See figures 4, 5, 6, and 7.)

\section{The Reactions}

Reactions were mixed and split along status lines. The proposed plan was generally accepted by the tenured librarians with minor adjustments. The covered librarians were generally opposed to it, believing it did not reflect their status or the responsibilities listed in the document, "Procedures for Initial Appointment, Reappointment, and Promotion for Covered Library Faculty." ${ }^{34}$ They were concerned that they would be forced to publish or suffer the consequences. This concern may have resulted from some confusion about the merit pay forms, since the forms would be tailored by one's immediate supervisor to each librarian's status and job responsibilities. Categories and percentages would differ between the groups. Since the total of the three cat- egories for both tenure or covered would equal $100 \%$, no group had an advantage over the other.

There was also concern among both the tenured and covered librarians that the rating was subjective and that supervisors could skew the results if desired. This is a valid point, but a built-in safeguard against this was the requirement that each librarian and his or her supervisor meet to detail one's responsibilities and note the importance of each. The system was transparent in that both the librarian and the supervisor knew in advance what was required. An additional safeguard suggested was that supervisors be trained in using a criterion-based weighted system.

A third major concern was that it was not known if the Acting University Librarian would be appointed to the position permanently or if a job search would be held. If a new University Librarian was hired, that person might not be interested in following the proposed procedures.

There was no consensus by the end of the meeting, so the issue was tabled. Both the tenured and covered groups were given the opportunity to discuss their concerns separately, within their own group. A special library faculty meeting would then be held to vote on the proposed policy or to table it. The few specific changes requested were made, and the revised documents were distributed.

\section{Meeting of the Covered Librarians}

Covered Library Faculty members met on December 11, 2007, to discuss merit pay. It quickly became apparent that there was strong opposition to the document. Some thought the document was too detailed. Others expressed concern that it added another layer of bureaucracy. It was also pointed out that an annual review process was already in place and that it should be the basis for a merit pay document. Finally, there was opposition to applying numerical values to a review. Since there is no standardized annual review template for the library, it was suggested that one be developed. Some suggested that 


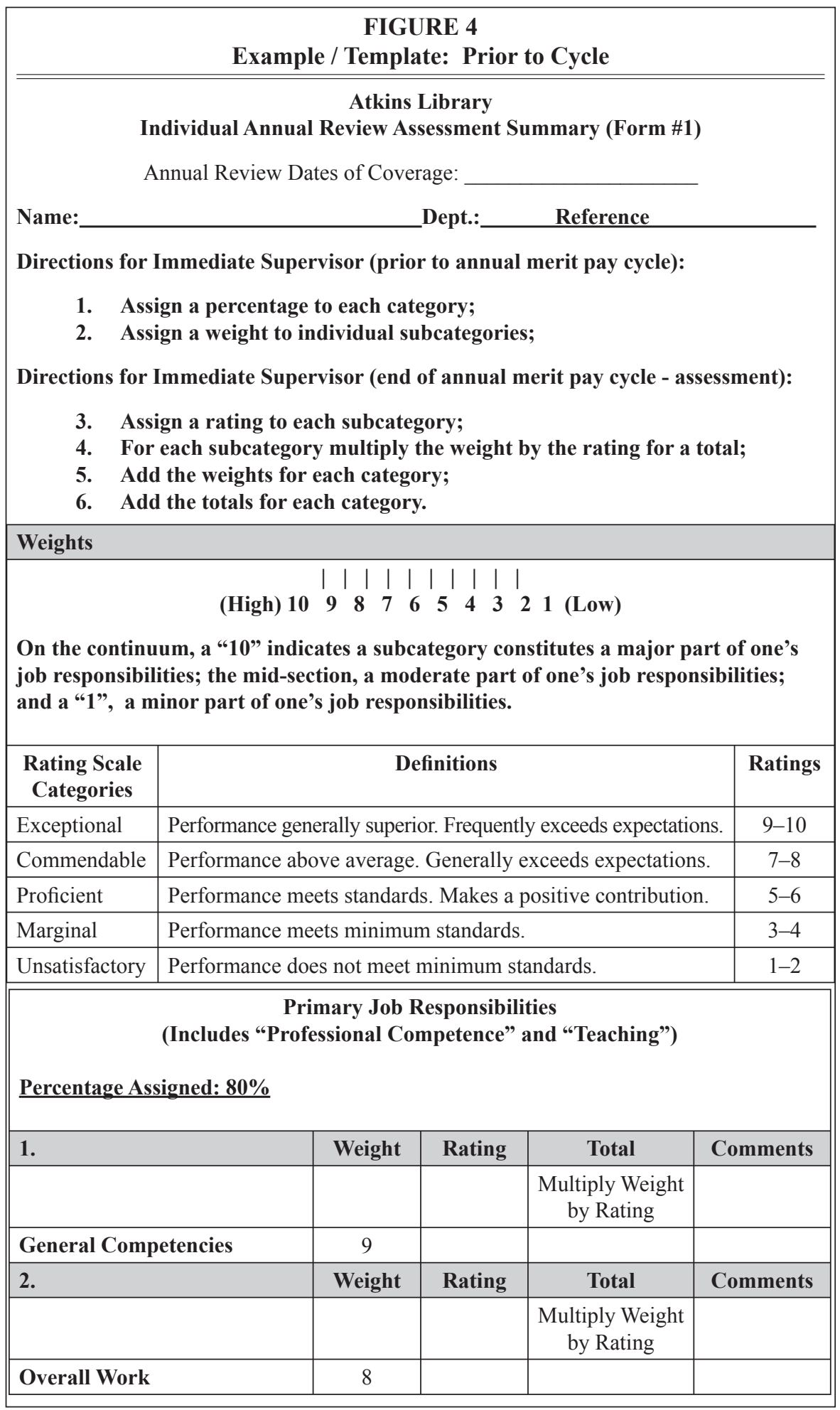




\begin{tabular}{|c|c|c|c|c|c|}
\hline \multicolumn{6}{|c|}{$\begin{array}{c}\text { FIGURE } 4 \text { (CONTINUED) } \\
\text { Example / Template: Prior to Cycle }\end{array}$} \\
\hline \multirow{2}{*}{\multicolumn{2}{|c|}{3.}} & Weight & Rating & Total & Comments \\
\hline & & & & $\begin{array}{l}\text { Multiply Weight } \\
\text { by Rating }\end{array}$ & \\
\hline \multicolumn{2}{|c|}{$\begin{array}{l}\text { Liaison Service to Faculty } \\
\text { (General) }\end{array}$} & 7 & & & \\
\hline \multirow{2}{*}{\multicolumn{2}{|c|}{4.}} & Weight & Rating & Total & Comments \\
\hline & & & & $\begin{array}{l}\text { Multiply Weight } \\
\text { by Rating }\end{array}$ & \\
\hline \multicolumn{2}{|c|}{ Reference Service } & 9 & & & \\
\hline \multirow{2}{*}{\multicolumn{2}{|c|}{5.}} & Weight & Rating & Total & Comments \\
\hline & & & & $\begin{array}{c}\text { Multiply Weight } \\
\text { by Rating }\end{array}$ & \\
\hline \multicolumn{6}{|c|}{ Collection Development } \\
\hline \multirow{2}{*}{\multicolumn{2}{|c|}{6.}} & Weight & Rating & Total & Comments \\
\hline & & & & $\begin{array}{l}\text { Multiply Weight } \\
\text { by Rating }\end{array}$ & \\
\hline \multicolumn{6}{|l|}{ Teaching } \\
\hline \multirow{2}{*}{\multicolumn{2}{|c|}{7.}} & Weight & Rating & Total & Comments \\
\hline & & & & $\begin{array}{l}\text { Multiply Weight } \\
\text { by Rating }\end{array}$ & \\
\hline \multicolumn{6}{|l|}{ Training } \\
\hline \multicolumn{6}{|c|}{ Total "Weight" for "Primary Job Responsibilities" } \\
\hline \multicolumn{6}{|c|}{ Total "Total" for "Primary Job Responsibilities" } \\
\hline \multicolumn{6}{|c|}{ Scholarship \& Research } \\
\hline \multirow[t]{2}{*}{1.} & Weight & & & Total & Comments \\
\hline & & & & $\begin{array}{l}\text { Multiply Weight } \\
\text { by Rating }\end{array}$ & \\
\hline Publications & 1 & & & & \\
\hline \multirow[t]{2}{*}{2.} & Weight & & & Total & Comments \\
\hline & & & & $\begin{array}{l}\text { Multiply Weight } \\
\text { by Rating }\end{array}$ & \\
\hline Conferences & NA & & & & \\
\hline \multicolumn{6}{|c|}{$\begin{array}{l}\text { Total "Weight" for "Scholarship \& Research" } \\
\text { Total "Total" for "Scholarship \& Research" }\end{array}$} \\
\hline
\end{tabular}




\begin{tabular}{|c|c|c|c|c|}
\hline \multicolumn{5}{|c|}{$\begin{array}{c}\text { FIGURE } 4 \text { (CONTINUED) } \\
\text { Example / Template: Prior to Cycle }\end{array}$} \\
\hline \multicolumn{5}{|c|}{ Service } \\
\hline 1. & Weight & Rating & Total & Comments \\
\hline & & & $\begin{array}{c}\text { Multiply Weight } \\
\text { by Rating }\end{array}$ & \\
\hline Committees & 2 & & & \\
\hline \multicolumn{5}{|c|}{$\begin{array}{l}\text { Total "Weight" for "Service" } \\
\text { Total "Total" for "Service" }\end{array}$} \\
\hline \multicolumn{5}{|l|}{ Signatures: } \\
\hline \multicolumn{3}{|c|}{ Immediate Supervisor } & \multicolumn{2}{|c|}{ Date: } \\
\hline \multicolumn{3}{|c|}{ University Librarian } & \multicolumn{2}{|c|}{ Date: } \\
\hline
\end{tabular}

a narrative summary of an employee's performance should be sufficient and that the Acting University Librarian could make a merit pay determination after reading the narrative. There was also a general discussion of training managers and supervisors in the process of how to evaluate a librarian. The overall suggestion was to abandon the document and start over with a new document directly tied to the annual review.

\section{Meeting of the Tenured Librarians}

The tenured faculty met on December 13, 2007, to discuss the criteria for merit pay documents. There was overall support for the document, although comments included the fact that the formulas were too confusing. It was also suggested that standard questions be used so that the University's automated scoring equipment Opscan could be used. This option was not viable since the instrument was designed to be flexible, recognizing individuals' status (tenured vs. covered) and job responsibilities. Another concern was the number of rating scale categories. The task forces proposed five categories: Exceptional (Performance generally superior. Frequently exceeds expectations.), Commendable (Performance above average. Generally exceeds expectations.), Proficient (Performance meets standards. Makes a positive contribution.), Marginal (Performance meets minimum standards.), and Unsatisfactory (Performance does not meet minimum standards.). It was suggested that three levels would be sufficient. It was agreed that this recommendation could easily be accommodated.

\section{Special Meeting of the Library Faculty}

A special meeting of the entire library faculty was held on December 13. The debate mirrored what had been stated at the first library faculty meeting and at the separate covered and tenured meetings. To a large extent, support of and opposition to the proposal reflected one's status, with covered librarians expressing greater opposition to the proposal. The major points of debate were: 1 ) dissatisfaction with the current lack of standardization regarding 


\section{FIGURE 5}

Example / Template: End of Cycle

\section{Atkins Library \\ Individual Annual Review Assessment Summary (Form \#1) \\ Annual Review Dates of Coverage:}

Name:

Dept.:

Reference

Directions for Immediate Supervisor (prior to annual merit pay cycle):

1. Assign a percentage to each category;

2. Assign a weight to individual subcategories;

Directions for Immediate Supervisor (end of annual merit pay cycle - assessment):

3. Assign a rating to each subcategory;

4. For each subcategory multiply the weight by the rating for a total;

5. Add the weights for each category;

6. Add the totals for each category.

\section{Weights}

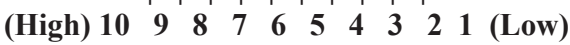

On the continuum, a "10" indicates a subcategory constitutes a major part of one's job responsibilities; the mid-section, a moderate part of one's job responsibilities; and a "1", a minor part of one's job responsibilities.

\begin{tabular}{|l|l|c|}
\hline $\begin{array}{c}\text { Rating Scale } \\
\text { Categories }\end{array}$ & \multicolumn{1}{|c|}{ Definitions } & Ratings \\
\hline Exceptional & Performance generally superior. Frequently exceeds expectations. & $9-10$ \\
\hline Commendable & Performance above average. Generally exceeds expectations. & $7-8$ \\
\hline Proficient & Performance meets standards. Makes a positive contribution. & $5-6$ \\
\hline Marginal & Performance meets minimum standards. & $3-4$ \\
\hline Unsatisfactory & Performance does not meet minimum standards. & $1-2$ \\
\hline
\end{tabular}

Primary Job Responsibilities

(Includes "Professional Competence" and "Teaching")

Percentage Assigned: $80 \%$

\begin{tabular}{|l|c|c|c|c||}
\hline 1. & Weight & Rating & Total & Comments \\
\hline & & & $\begin{array}{c}\text { Multiply Weight } \\
\text { by Rating }\end{array}$ & \\
\hline General Competencies & 9 & 5 & 45 & \\
\hline 2. & Weight & Rating & Total & Comments \\
\hline & & & $\begin{array}{c}\text { Multiply Weight } \\
\text { by Rating }\end{array}$ & \\
\hline Overall Work & 8 & 7 & 56 & \\
\hline
\end{tabular}


One Library's Attempt to Put "Merit" Back in "Merit Pay" 49

FIGURE 5 (CONTINUED)

Example / Template: End of Cycle

\begin{tabular}{|c|c|c|c|c|}
\hline 3. & Weight & Rating & Total & Comments \\
\hline & & & $\begin{array}{c}\text { Multiply Weight } \\
\text { by Rating }\end{array}$ & \\
\hline $\begin{array}{l}\text { Liaison Service to Faculty } \\
\text { (General) }\end{array}$ & 7 & 5 & 35 & \\
\hline \multirow[t]{2}{*}{4.} & Weight & Rating & Total & Comments \\
\hline & & & $\begin{array}{c}\text { Multiply Weight } \\
\text { by Rating }\end{array}$ & \\
\hline Reference Service & 9 & 7 & 63 & \\
\hline \multirow[t]{2}{*}{5.} & Weight & Rating & Total & Comments \\
\hline & & & $\begin{array}{c}\text { Multiply Weight } \\
\text { by Rating }\end{array}$ & \\
\hline \multicolumn{5}{|l|}{ Collection Development } \\
\hline \multirow[t]{2}{*}{6.} & Weight & Rating & Total & Comments \\
\hline & & & $\begin{array}{c}\text { Multiply Weight } \\
\text { by Rating }\end{array}$ & \\
\hline \multicolumn{5}{|l|}{ Teaching } \\
\hline \multirow[t]{2}{*}{7.} & Weight & Rating & Total & Comments \\
\hline & & & $\begin{array}{c}\text { Multiply Weight } \\
\text { by Rating }\end{array}$ & \\
\hline \multicolumn{5}{|l|}{ Training } \\
\hline \multicolumn{3}{|c|}{$\begin{array}{l}\text { Total "Weight" for "Primary Job Responsibilities" } \\
\text { Total "Total" for "Primary Job Responsibilities" }\end{array}$} & $\begin{array}{c}33 \\
199 \\
\end{array}$ & \\
\hline
\end{tabular}

Percentage Assigned: 10\%

Scholarship \& Research

\begin{tabular}{|c|c|c|c|c|}
\hline 1. & Weight & Rating & Total & Comments \\
\hline & & & $\begin{array}{l}\text { Multiply Weight } \\
\text { by Rating }\end{array}$ & \\
\hline Publications & 1 & 8 & 8 & \\
\hline 2. & Weight & Rating & Total & Comments \\
\hline & & & $\begin{array}{l}\text { Multiply Weight } \\
\text { by Rating }\end{array}$ & \\
\hline Conferences & NA & NA & NA & \\
\hline \multicolumn{3}{|c|}{$\begin{array}{l}\text { Total "Weight" for "Scholarship \& Research" } \\
\text { Total "Total" for "Scholarship \& Research" }\end{array}$} & $\begin{array}{l}1 \\
\end{array}$ & \\
\hline
\end{tabular}


FIGURE 5 (CONTINUED)

Example / Template: End of Cycle

\begin{tabular}{|l|c|c|c|c||}
\hline \hline \multicolumn{4}{|l||}{ Service } \\
\hline Percentage Assigned: 10\% & Reight & Rating & Total & Comments \\
\hline 1. & & & $\begin{array}{c}\text { Multiply Weight } \\
\text { by Rating }\end{array}$ & \\
\hline & 2 & 7 & 14 & \\
\hline Committees & Wotal "Weight" for "Service" & $\frac{\mathbf{2}}{\mathbf{1 4}}$ & \\
\hline \begin{tabular}{l} 
Total "Total" for "Service" \\
\hline
\end{tabular}
\end{tabular}

Signatures:

Immediate Supervisor

Date:

University Librarian

Date:

Note: Signing by the Librarian under review does not indicate agreement.

how annual self-evaluations are written; 2) lack of definitions for "scholarship" and "service"; 3) the belief that too much work would be required of managers; and 4) the perception of a disconnect between the proposal and the current system.

Some issues extended beyond the charge of the task force, although several good suggestions were made that the Library Administration may wish to implement. One of these suggestions was to standardize how individuals write self-evaluations. Although goal setting is currently in place for both tenured and covered library faculty, Library Administration may need to reiterate that goals must be included in annual reviews.

Another issue brought forward by the faculty was the lack of definition regarding service and scholarship. This issue may be something that covered and tenured librarians must address in their respective governing documents. While this lack of definition is a valid concern and critical to reappointment, tenure, and promotion, it does not impact annual administrative reviews.
No vote was taken on the proposal. Instead, a vote was taken to adjourn the meeting. This left open three possibilities for the library faculty: 1) have another special library faculty meeting regarding the proposal; 2) discuss the proposal again at the next regular library faculty meeting; or 3) allow the proposal to die. Those present agreed they wanted to continue a discussion about merit pay criteria, but they did not want it to center around the current proposal. The Acting University Librarian thanked the task forces and said their work was concluded.

\section{Conclusion}

Although the proposal was ultimately rejected, the authors believe the proposal accomplished five major things:

1. Individuals' responsibilities were tied to the goals of their units.

2. Job responsibilities were ranked as to importance.

3. It integrated the status and responsibilities of the tenured and covered librarians into a cohesive process. 


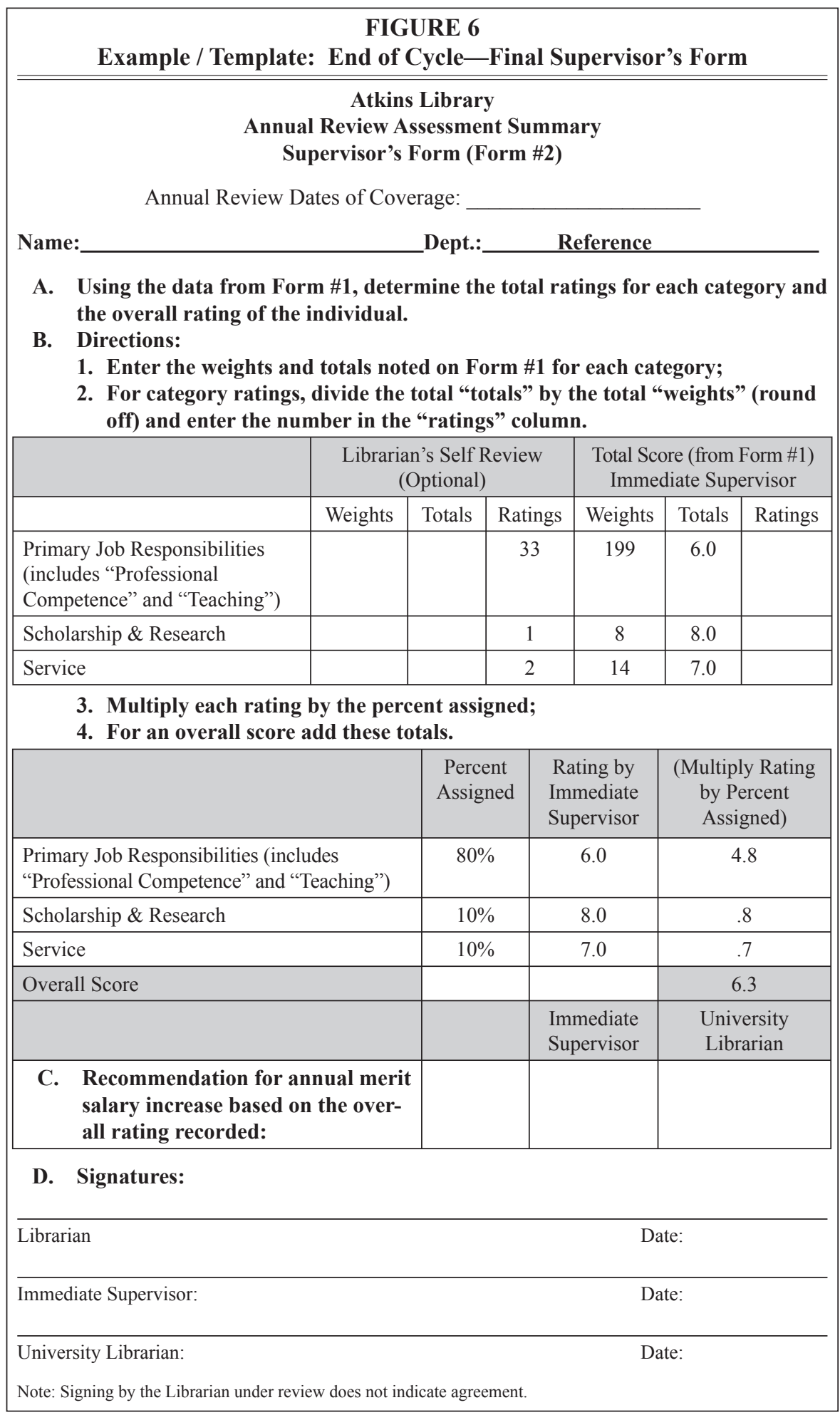




\section{FIGURE 7}

\section{Step by Step Instructions (with Examples)}

- The immediate supervisor and librarian apply percentages to each category and records these on Form \#1:

For example, Primary Job Responsibilities - 80\%; Scholarship \& Research $-10 \%$,

Service $-10 \%$

- The immediate supervisor and librarian determine subcategories of responsibilities under each of the categories and records these on Form \#1:

For example, under "Primary Job Responsibilities" Reference may choose:

- "Reference Services"

- "Liaison Services to Faculty"

- "Teaching"

- The immediate supervisor assigns weights to individual subcategories, 1 being the lowest and 10 being the highest. The immediate supervisor records these on Form 1.

$$
\text { (High) } 10 \begin{array}{lll|l|l|l|l|l|lll}
\mid & \mid & \mid & \mid & \mid & \mid & \mid & & & \\
\hline 9 & 8 & 7 & 6 & 5 & 4 & 3 & 2 & 1 & \text { (Low) }
\end{array}
$$

On the continuum, a "10" indicates a subcategory constitutes a major part of one's job responsibilities; the mid-section, a moderate part of one's job responsibilities; and a "1", a minor part of one's job responsibilities.

\begin{tabular}{|l|l|}
\hline Weights & Definitions \\
\hline $10-9$ & Critical for position \\
\hline $8-7$ & Essential for position \\
\hline $6-5$ & Important for position \\
\hline $4-3$ & Necessary for position \\
\hline $2-1$ & Useful for position \\
\hline
\end{tabular}

For example, "Liaison Service to Faculty" is assigned a weight of "7".

\begin{tabular}{|l|l|l|c|}
\hline 3. & Weight & Rating & Total \\
\hline & & & $\begin{array}{c}\text { Multiply Weight } \\
\text { by Rating }\end{array}$ \\
\hline $\begin{array}{l}\text { Liaison Service to } \\
\text { Faculty (General) }\end{array}$ & 7 & & \\
\hline
\end{tabular}

- Individual librarian meets with his/her immediate supervisor prior to the next review period to review the job description, establish goals for the upcoming year, add or modify individual-specific subcategories as applies to an individual's responsibilities, and record the data on Form 1;

- Individual librarians and immediate supervisors meet in mid-year to review the above and revise as appropriate;

- At the end of the year, the immediate supervisor rates each librarian:

1. The immediate supervisor assigns a "rating" for each individual subcategory. The immediate supervisor records these on Form 1. 


\section{FIGURE 7 (CONTINUED) \\ Step by Step Instructions (with Examples)}

- Individual librarians and immediate supervisors meet in mid-year to review the above and revise as appropriate;

- At the end of the year, the immediate supervisor rates each librarian:

1. The immediate supervisor assigns a "rating" for each individual subcategory. The immediate supervisor records these on Form 1.

\begin{tabular}{|l|l|c|}
\hline \multicolumn{1}{|c|}{$\begin{array}{c}\text { Rating Scale } \\
\text { Categories }\end{array}$} & \multicolumn{1}{|c|}{ Definitions } & Ratings \\
\hline Exceptional & $\begin{array}{l}\text { Performance generally superior. Frequently } \\
\text { exceeds expectations. }\end{array}$ & $9-10$ \\
\hline Commendable & $\begin{array}{l}\text { Performance above average. Generally exceeds } \\
\text { expectations }\end{array}$ & $7-8$ \\
\hline Proficient & $\begin{array}{l}\text { Performance meets standards. Makes a positive } \\
\text { contribution }\end{array}$ & $5-6$ \\
\hline Marginal & Performance meets minimum standards & $3-4$ \\
\hline Unsatisfactory & Performance does not meet minimum standards & $1-2$ \\
\hline
\end{tabular}

For example, a rating of "5" (Proficient) is assigned to an individual for "Liaison Service to Faculty".

\begin{tabular}{|l|l|l|c|}
\hline 3. & Weight & Rating & Total \\
\hline & & & $\begin{array}{c}\text { Multiply Weight } \\
\text { by Rating }\end{array}$ \\
\hline Liaison Service to Faculty (General) & 7 & 5 & \\
\hline
\end{tabular}

2. The immediate supervisor multiplies the "weight" by the "rating" for each subcategory, e.g. For "Liaison Service to Faculty" $7 \times 5=35$. The immediate supervisor records these on Form 1.

\begin{tabular}{|l|l|l|c|}
\hline 3. & Weight & Rating & Total \\
\hline & & & $\begin{array}{c}\text { Multiply Weight } \\
\text { by Rating }\end{array}$ \\
\hline Liaison Service to Faculty (General) & 7 & 5 & 35 \\
\hline
\end{tabular}

3. The immediate supervisor adds the total "weights" and the total "totals" for each category. The immediate supervisor records these on Form 1.

For example:

- For the category "Primary Job Responsibilities" the total "weights" = 33 and the total "totals" $=199$

- For the category "Scholarship \& Research" the total "weights" = 1 and the total "totals" $=8$

- For the category "Service" the total "weights" = 2 and the total "totals" = 14 


\begin{tabular}{|l|l|l|l|c|c|c|}
\hline \multicolumn{7}{|c|}{ FIGURE 7 (CONTINUED) } \\
\hline \hline \\
\hline $\begin{array}{l}\text { The immediate supervisor transfers the weights and totals noted on Form \#1 } \\
\text { for each category on Form \#2. }\end{array}$ \\
\hline & \multicolumn{2}{|c|}{$\begin{array}{c}\text { Librarian's Self Review } \\
\text { (Optional) }\end{array}$} & \multicolumn{2}{c|}{$\begin{array}{c}\text { Total Score (from Form \#1) } \\
\text { Immediate Supervisor }\end{array}$} \\
\hline $\begin{array}{l}\text { Primary Job Responsibilities } \\
\text { (includes "Professional Com- } \\
\text { petence" and "Teaching") }\end{array}$ & & & & 33 & 199 & \\
\hline Scholarship \& Research & & & & 1 & 8 & \\
\hline Service & & & & 2 & 14 & \\
\hline
\end{tabular}

5. To arrive at category ratings, the immediate supervisor divides the "totals" by the "weights" (rounding off) and enters the results in the "ratings" column on Form \#2.

\begin{tabular}{|l|c|c|c|c|c|c|}
\hline & \multicolumn{2}{|c|}{$\begin{array}{c}\text { Librarian's Self Review } \\
\text { (Optional) }\end{array}$} & \multicolumn{2}{c|}{$\begin{array}{c}\text { Total Score (from Form \#1) } \\
\text { Immediate Supervisor }\end{array}$} \\
\hline & Weights & Totals & Ratings & Weights & Totals & Ratings \\
\hline $\begin{array}{l}\text { Primary Job Responsibilities (in- } \\
\text { cludes "Professional Competence" } \\
\text { and "Teaching") }\end{array}$ & & & & 33 & 199 & 6.0 \\
\hline Scholarship \& Research & & & & 1 & 8 & 8.0 \\
\hline Service & & & & 2 & 14 & 7.0 \\
\hline
\end{tabular}

6. The immediate supervisor multiplies each rating by the percent assigned and records the numbers on Form \#2.

\begin{tabular}{|l|c|c|c|}
\hline & $\begin{array}{c}\text { Percent } \\
\text { Assigned }\end{array}$ & $\begin{array}{c}\text { Rating by Immediate } \\
\text { Supervisor }\end{array}$ & $\begin{array}{c}\text { (Multiply Rating by } \\
\text { Percent Assigned) }\end{array}$ \\
\hline $\begin{array}{l}\text { Primary Job Responsibilities } \\
\text { (includes "Professional Compe- } \\
\text { tence" and "Teaching") }\end{array}$ & $80 \%$ & 6.0 & 4.8 \\
\hline Scholarship \& Research & $10 \%$ & 8.0 & .8 \\
\hline Service & $10 \%$ & 7.0 & .7 \\
\hline Overall Score & & & \\
\hline
\end{tabular}

7. To arrive at an overall score, the percents in the last column are added, recorded off, and recorded on Form \#2. In this example, the librarian's overall score is 6.3 (A bit better than "Proficient").

\begin{tabular}{|l|c|c|c|}
\hline & $\begin{array}{c}\text { Percent } \\
\text { Assigned }\end{array}$ & $\begin{array}{c}\text { Rating by Immediate } \\
\text { Supervisor }\end{array}$ & $\begin{array}{c}\text { (Multiply Rating by } \\
\text { Percent Assigned) }\end{array}$ \\
\hline $\begin{array}{l}\text { Primary Job Responsibilities } \\
\text { (includes "Professional Compe- } \\
\text { tence" and "Teaching") }\end{array}$ & $80 \%$ & 6.0 & 4.8 \\
\hline Scholarship \& Research & $10 \%$ & 8.0 & .8 \\
\hline Service & $10 \%$ & 7.0 & .7 \\
\hline Overall Score & & & 6.3 \\
\hline
\end{tabular}




\begin{tabular}{|c|c|c|}
\hline \multicolumn{3}{|c|}{$\begin{array}{c}\text { FIGURE } 7 \text { (CONTINUED) } \\
\text { Step by Step Instructions (with Examples) }\end{array}$} \\
\hline & $\begin{array}{l}\text { ides a recommendatio } \\
\text { ssment documentation }\end{array}$ & $\begin{array}{l}\text { for annual merit sal- } \\
\text { see below). }\end{array}$ \\
\hline & Immediate Supervisor & University Librarian \\
\hline $\begin{array}{l}\text { C. Recommendation for annual merit } \\
\text { salary increase based on the overall } \\
\text { rating recorded: }\end{array}$ & & \\
\hline \multicolumn{3}{|c|}{$\begin{array}{l}\text { - The librarian may also provide "self review" measurements; } \\
\text { - These are recorded on the "Annual Review Assessment Summary Supervisor's Form" } \\
\text { and forwarded to the University Librarian; }\end{array}$} \\
\hline \multicolumn{3}{|c|}{$\begin{array}{l}\text { Complete Assessment Documentation: } \\
\text { - The Librarian's annual self evaluation plus any other documents s/he chooses to submit; } \\
\text { - The immediate supervisor's rating (Numerical Forms } 1 \text { and 2); } \\
\text { - The immediate supervisor's annual evaluation }\end{array}$} \\
\hline
\end{tabular}

4. It brought some measurable accountability to a subjective process.

5. It offered transparency.

A positive result of the committees' work is that it opened a dialogue on the broader issues revolving around annual evaluations and how merit pay is awarded. It also demonstrated that the Acting University Librarian acknowledged concerns about the weaknesses of the current process and wanted to correct it. However, it also exposed some fundamental climate issues between tenured librarians and their covered colleagues. While these status issues may have always been just beneath the surface, the attempt to redesign the merit pay process made them the focal point of a formal discussion for the first time. The authors' hope is that future discussions will result in a workable, measurable assessment tool acceptable to all.

\section{Notes}

1. University of North Carolina at Charlotte, "UNC Charlotte Facts" (June 2007). Available online at www.provost.uncc.edu/Catalogs/2007-2009/unccfacts.htm. Accessed [date].

2. University of North Carolina at Charlotte, "Tenure Policies, Regulations, and Procedures of the University of North Carolina at Charlotte" (Apr. 20, 2007). Available online at www.legal. uncc.edu/tenurepol.html. Accessed [date].

3. Lou Anderson and Donnice Cochenour, "Merit Salary Criteria: One Academic Library's Experience," Libraries and the Academy 1 (2001), 470.

4. David A. Baldwin, The Library Compensation Handbook: A Guide for Administrators, Librarians, and Staff (Westport, Conn.: Libraries Unlimited, 2003), 67.

5. Ibid, 70 .

6. Ibid, 70-71.

7. Richard I Henderson, Compensation Management in a Knowledge-Based World, 8th ed. (Saddle River, N.J.: Prentice-Hall, 2003), 395.

8. Carol F. Goodson, The Complete Guide to Performance Standards for Library Personnel (New York: Neal Schuman Publishers, 1997).

9. Patricia Belcastro, Evaluating Library Staff: A Performance Appraisal System (Chicago: American Library Association, 1998).

10. Scott Seaman, Carol Krismann, and Fred Hamilton, "An Internal Equity Evaluation System Based on Merit Measures," College \& Research Libraries 60 (Jan. 1999): 4.

11. Henderson, Compensation Management in a Knowledge-Based World, 409.

12. Indiana University Bloomington Libraries, Bloomington Library Faculty Council, 
"Peer Review in Annual Merit Evaluation" (Apr. 2, 2003). Available online at www.indiana. edu/ libblfc/20022003/peerreviewrevised.html. Accessed March 30, 2008.

13. Temple University, "Guidelines for Merit Pay" (n.d.). Available online at www.temple. edu/vpfaculty/Merit_Forms/Merit_Guidelines.pdf. Accessed March 29, 2008.

14. Policies and Practices (Boston: Warren, Gorham and Lamont, 1994), vol. 3; 151: 3303.

15. Anderson and Cochenour, "Merit Salary Criteria: One Academic Library's Experience," 469.

16. Ibid.

17. Lawrence Nurse, "Performance Appraisal, Employee Development and Organizational Justice: Exploring the Linkages," International Journal of Human Resources Management 16 (July 2005): 1179 .

18. Ibid.

19. A. Dubrin, Winning Office Politics: Dubrin's Guide for the '90s (Englewood Cliffs, N.J.: Prentice Hall, 1990); L. Bolhman and T.E. Deal, Reframing Organizations: Artistry, Choice and Leadership (San Francisco, Calif.: Jossey-Bass, 1991); M.M. Kennedy, Office Politics: Seizing Power, Wielding Clout (New York: Warner Books, 1980), quoted in Nurse, "Performance Appraisal, Employee Development and Organizational Justice: Exploring the Linkages," 1179.

20. E.E. Lawler, Pay and Organizational Effectiveness: A Psychological View (New York, N.Y.: McGraw-Hill, 1971), quoted in Marc Siegall and Chuck Worth, "The Impacts of Trust and Control on Faculty Reactions to Merit Pay," Personnel Review 30 (2001): 646.

21. R. Folger and R.S. Cropanzano, Organizational Justice and Human Resource Management (Thousand Oaks, Calif.: Sage, 1998) quoted in Nurse, "Performance Appraisal, Employee Development and Organizational Justice: Exploring the Linkages," 1177.

22. Sylvie St-Onge, "Variables Influencing the Perceived Relationship between Performance and Pay in a Merit Pay Environment," Journal of Business and Psychology 14 (Spring 2000): 460.

23. Charles B. Lowry and Paul J. Hanges. "What Is the Health Organization: Organizational Climate and Diversity Assessment: A Research Partnership," Libraries and the Academy 8 (2008): 3-4.

24. Miluse Soudak, "Organizational Climate and Professional Behavior of Academic Librarians," Journal of Academic Librarianship 8 (1983): 334-37. 467.

25. Anderson and Cochenour, "Merit Salary Criteria: One Academic Library's Experience,"

26. Frederick W. Cook, "Merit Pay and Performance Appraisal," quoted in Anderson and Cochenour, "Merit Salary Criteria: One Academic Library's Experience," 467.

27. H. Rebecca Kroll, "Beyond Evaluation: Performance Appraisal as a Planning and Motivational Tool in Libraries," Journal of Academic Librarianship 9 (1983), 28, quoted in Anderson and Cochenour, "Merit Salary Criteria: One Academic Library's Experience," 468.

28. Henderson, Compensation Management in a Knowledge-Based World, 430.

29. University of North Carolina at Charlotte, "Peer Institutions for UNC Charlotte" (n.d.). Available online at www.uncc.edu/apir/irmainpage2/Sis_Schools.html. Accessed February 26, 2008.

30. University of North Carolina at Charlotte, "Tenured Policies and Regulations of the Library Faculty at the University of North Carolina at Charlotte" (2007). Available online at http://library. uncc.edu/files/33/faculty/tenure/Library_Tenure_doc_April_2007_Approved.pdf. Accessed February 27, 2008.

31. University of North Carolina at Charlotte, "Academic Personnel Procedures Handbook, Academic Personnel Review Process, Annual Review: Procedures for Annual Review of Members of the Faculty" (n.d.). Available online at www.provost.uncc.edu/epa/handbook/chapter_VI.htm\#B. Accessed March 13, 2008.

32. E-mails obtained from UNC Charlotte Peer Institutions.

33. Pay for Performance: Evaluating Performance Appraisal and Merit Pay, eds. George T. Milkovich and Alexandra K. Wigdor (Washington, D.C.: National Academic Press, 1991), 143-44, quoted in Anderson and Cochenour, "Merit Salary Criteria: One Academic Library's Experience," 469 and Henderson, Compensation Management in a Knowledge-Based World, 430-32.

34. University of North Carolina at Charlotte, "Procedures for Initial Appointment, Reappointment, and Promotion for Covered Library Faculty at the University of North Carolina at Charlotte" (2003). Available online at http://library.uncc.edu/files/33/faculty/covered/coveredlibraryfaculty12-04-03.doc. Accessed March 13, 2008. 